\title{
Den gode præsentation - akademisk mundtlig fremstilling og personlig kommunikation
}

\author{
Anmeldelse af Sussi Louise Zimmermann, UNIPAED, Roskilde Universitet
}

Den gode presentation - akademisk mundtlig fremstilling og personlig kommunikation,

Linda Greve

Forlaget Samfundslitteratur, 2010,

187 sider

ISBN: 978-87-593-1431-9

"Den gode prosentation « byder på en dannelsesrejse gennem en vigtig del af det brogede, pædagogiske landskab, nemlig den mundtlige præsentation. Rejsen strækker sig fra Aristoteles, over Descartes og Toulmin, til Scharmer og frem til Greve i 2010, som her præsenterer ideen om relationel kommunikation og læring.

Forfatteren Linda Greve, cand. theol., retoriker og journalist, stiller i bogen det klassiske universitetspædagogiske spørgsmål: »Hvordan præsenteres kompleks viden på en måde, så det giver mening for folk? «. Svaret formulerer hun i det dobbelte imperativ: 1) Gennem solid metodisk forberedelse og 2) talerens mod til at indgå i en relation til sin lytter.

I årevis har jeg ledt efter en bog, som var tilpas akademisk til at være attraktiv i universitetspædagogisk professionaliseringsøjemed og alligevel grundlæggende nok til at præsentere erfarne praktikere for læringsteori og tænkning, som de ikke hidtil har haft et fagsprog- og teoriapparat for, vel at mærke uden at virke fremmedgørende. Bogen er universitetspædagogik og præsentationsmetode på et højt fagligt og reflekteret niveau, og den fokuserer på talerens refleksion, læring og dygtiggørelse; desuden forholder den sig til 'det særegent akademiske': Faglighed, en grundindstilling af undren og evnen til undersøgelse - hos taler såvel som hos lytter.

Bogen er opdelt $i$ to dele, $i$ alt syv kapitler. Læsevejledningen i kapitel et er en god indgang til forståelsen af bogens indre logik. I kapitel to indføres læseren i lærings- og kommunikationsteoretiske begreber og paradigmer introduceret på et højt, men stadig tilgængeligt niveau. Linda Greve placerer sig i dette teoretiske kapitel stærkt i den moderne kommunikationsteoris relationsparadigme (47). I kapitel to tager forfatteren læseren med ud på en potentielt skelsættende 'havevandring', en metafor vi kender fra stage-gate modellerne (Cooper 2000). Dette er i tråd med hendes anbefaling om udvidet brug af metaforer i præsentationer, og hun bruger i bogen selv kontinuerligt billedsprog til at fremme sine pointer og relationen til læseren. Hvert kapitel afsluttes ved en 'låge', der opsummerer kapitlets hovedpointer.

De næstfølgende fem kapitler udgør bogens anden del. Progressionen er logisk og systematisk lineært struktureret i henhold til Aristoteles fem forberedelsesfaser (partes) som hos Linda Greve er karakteriseret ved strenge regler for progression: inventio, dispositio, elucutio, memoria og actio.

Hovedpointerne om metodisk forberedelse og relationen til lytterne er gennemgående temaer i bogen. En god præsentation handler om at "mærke og spejle lytterne (Bauer) og om at holde sig for øje, hvad du vil dem med din præsentation" (176). For taleren betyder dette, at "lytteren skal føle sig involveret og aktivt lyttende, og den viden, der formidles, skal være relevant og vedkommende« (47). Det er imperativt i Greves læringsforståelse, at taleren skaber relation med sine lyttere og undervejs afstemmer sit oplæg til lytternes signaler, samt at taleren kan fastholde og vende tilbage til præsentationens budskaber og hensigter, uanset hvor diskussionen måtte bevæge sig hen. Desværre adresserer forfatteren ikke den større udfordring, det vil være, når man som taler står foran 200 lyttere frem for f.eks. 20 .

I tråd med bogens metode kastede jeg mig selv ud i den store, guidede 'havevandring' og gik i gang med modeltegning, brainstorming og argumentationsvalg. Jeg lavede strategier for imødekommelse af lærings- 
stile og anvendelse af billedsprog; reflekterede over kropssprog og visuelt udtryk. Først ved fjerde 'låge' påbegyndte jeg PowerPoint præsentationen og startede, som anbefalet, med første og sidste slide - godt råd forresten. I undervisningssituationen fulgte jeg også anbefalingerne og ledsagede gerne lytterne ud ad sidespor og førte senere præsentationen tilbage til de planlagte budskaber og hensigter. Det var en virkelig god oplevelse. Og virkelig tidskrævende. Men som med de fleste refleksive pædagogiske metoder vil tidsforbruget højst sandsynligt falde, efterhånden som den nye praksis bliver en del af ens aktive pædagogiske repertoire.

Linda Greve anbefaler, at man slavisk læser og afprøver hele metoden i praksis, før man kan vende tilbage og bruge bogen til opslag. Netop dette anser jeg som en af bogens største akilleshæle. "Den gode presentation" er en bog af høj faglig kvalitet og væsentlighed, men set $i$ forhold til de udfordringer, underviserne står overfor i deres hverdagspraksis, kan metoden opfattes som omstændig og lettere idylliseret. Ikke mindst fordi mange undervisere laver præsentationer i randområderne af deres disciplin og forskningsfelt. Hvilket bevirker, at de ikke kun koncentrerer sig om planlægningen af undervisningen, men også ofte bruger tid på at sætte sig ind i nye stofområder.

Har man tiden, anbefaler jeg varmt den engagerede underviser, der har til opgave at lave en (god!) præsentation, at kaste sig ud i Linda Greves opskrift. Det er en inspirerende og lærerig proces, som utvivlsomt, hvis alle 'låger' er blevet åbnet, vil være med til såvel at højne det kvalitative niveau af præsentationer ved universiteterne, som at hæve talerens oplevelse af underviserprofessionalitet. Det kan kun være godt! 